\title{
Relating Objective and Subjective Ratings of Snap Bean Pod Color to Likelihood of Purchase
}

\author{
Brian A. Kahn ${ }^{1,3}$ and William G. McGlynn ${ }^{2}$ \\ Department of Horticulture and Landscape Architecture, Oklahoma State \\ University, 360 Agricultural Hall, Stillwater, OK 74078-6027
}

Additional index words. Phaseolus vulgaris, greenness, hue angle, $\mathrm{L}^{*}$ value, sensory panel

\begin{abstract}
Snap bean (Phaseolus vulgaris L.) cultivars with pods representing a range of greenness were grown in Oklahoma field trials in 2001 and 2004. Objective color evaluations ( $L^{*}$ value and hue angle) performed on raw and cooked pod samples from 10 (2001) or 12 (2004) of these cultivars indicated that color testing of raw snap bean pods may not be sufficient to determine the color after cooking. Although $L^{*}$ values may be expected to decrease after cooking, the magnitude of the changes may not be predictable. Changes in hue angle values after cooking appear to be even more variable among cultivars. Therefore, if the color of the cooked beans is expected to be a deciding factor in cultivar selection, we would recommend conducting color tests on cooked bean pods as well as the raw product. Twenty relatively straight, unblemished pods per cultivar were harvested on 20 June 2001 and on 30 June 2004 from plants of 'Blue Lake 274', 'Brio', 'Charon', 'Jade', and 'Seville'. The five most uniform pods per cultivar (all sieve Size 4) were presented as raw samples that same day to an untrained panel consisting of seven males and 18 females (2001) or nine males and 18 females (2004). This was an affective test; panelists were asked to evaluate intensity of color and likeliness to buy using a 5point semantic differential scale. Correlation coefficients for the two attributes were calculated. Sensory panelists were able to make subjective distinctions among the cultivars based on color. However, these differences did not necessarily correlate with either objective color measures or likelihood of purchase. Snap bean pod color is not an overriding selection criterion, but only one of many criteria considered by consumers.
\end{abstract}

Color and appearance factors are the primary quality attributes that can be appraised by consumers of fresh produce at the time of purchase (Gamble et al., 2006; Kramer, 1951). Historically, the snap beans purchased by U.S. consumers were a relatively light shade of green. However, in the 1990 s, a major seed company introduced dark green beans to the U.S. fresh market (Brooker and Eastwood, 1992). The company promoted the dark green beans as being more attractive to buyers, but little objective information was available to back these claims. Moreover, it was not known how color might change after the dark green beans were cooked.

\footnotetext{
Received for publication 2 Dec. 2008. Accepted for publication 10 Feb. 2009.

Approved for publication by the Director, Oklahoma Agricultural Experiment Station.

This research was supported in part under project H-2026.

We gratefully acknowledge the technical assistance of Lynda Carrier.

The information given in this publication is for educational purposes only. Mention of a trademark, proprietary product, or vendor does not constitute a guarantee or warranty of the product nor does it imply approval or disapproval to the exclusion of other products or vendors that may also be suitable. ${ }^{1}$ Professor.

${ }^{2}$ Associate Professor.

${ }^{3}$ To whom reprint requests should be addressed; e-mail brian.kahn@okstate.edu.
}

The human eye can perceive visual differences in greenness among fresh samples of snap bean pods (Hoffman and Kanapaux, 1955). It is less well understood how these subjective distinctions relate to both objective measures of greenness and subjective ratings for likelihood of purchase. Hoffman and Kanapaux (1955) found a significant correlation ( $r=0.906, P \leq 0.01)$ between visual color ratings and chlorophyll content of fresh snap bean pods, but chlorophyll is not the only pigment responsible for color in snap beans (Lopez-Hernandez et al., 1993). Brooker and Eastwood (1992) surveyed shoppers for selection preference when comparing fresh pods of the light green 'Strike' and the dark green 'Labrador' snap beans. They found a slight preference $(52.2 \%)$ for the light green cultivar, but they did not attempt to relate these preferences to any objective measures of greenness.

Lee (1958) noted that when green vegetables are heated in water, the chloroplasts become swollen and may burst, resulting in a diffusion of green pigment throughout the cells and a more intense green appearance to the surface of the vegetable. Muftugil (1986) found that bean samples blanched with water or steam were more green than raw beans, but cultivars were not compared for possible differential responses.

The objectives of this study were: 1) to perform objective color evaluations on raw and cooked pod samples from several snap bean cultivars with pods representing a range of greenness; and 2) to determine whether consumers could distinguish differences in greenness among raw pod samples from several of these cultivars and, if so, whether these subjective distinctions would relate to both objective measures of greenness and subjective ratings for likelihood of purchase.

\section{Materials and Methods}

Field production trials. Studies were conducted at the Oklahoma Vegetable Research Station, Bixby, in 2001 and 2004. The soil was a Severn very fine sandy loam [coarsesilty, mixed (calcareous), thermic Typic Udifluvent]. Weeds were controlled with a broadcast preplant-incorporated application of trifluralin at $560 \mathrm{~g} \cdot \mathrm{ha}^{-1}$ supplemented by hand and machine cultivation in both years. Plant water requirements were met with rainfall supplemented by overhead sprinkler irrigation. Standard foliar insecticides were applied as needed.

In 2001, a broadcast preplant-incorporated application of $48 \mathrm{~N}-21 \mathrm{P}-39 \mathrm{~K}\left(\mathrm{~kg} \cdot \mathrm{ha}^{-1}\right)$ was made on 3 Apr. Plants were topdressed with urea to supply $34 \mathrm{~kg} \cdot \mathrm{ha}^{-1}$ nitrogen $(\mathrm{N})$ on 17 May. In 2004, a broadcast preplant-incorporated application of $29 \mathrm{~N}-13 \mathrm{P}-24 \mathrm{~K}\left(\mathrm{~kg} \cdot \mathrm{ha}^{-1}\right)$ was made on 2 Apr. Plants were topdressed with urea to supply $34 \mathrm{~kg} \cdot \mathrm{ha}^{-1} \mathrm{~N}$ per application on 20 May and 11 June.

Thirteen snap bean cultivars were used in 2001 (Table 1) and 12 cultivars were used in 2004 (Table 2). Those represented by the seed companies as "dark green" included 'Charon', 'Dusky', 'Jade', and 'Savannah'. The seed companies discontinued 'Castano', 'Hialeah', and 'Mercury' between 2001 and 2004. The experimental design was a randomized complete block with three replications. Seeds were sown by machine in rows that were $90 \mathrm{~cm}$ apart on $27 \mathrm{Apr} .2001$ and on 29 Apr. 2004. No inoculants were used. Stands were thinned to 60 plants in $6 \mathrm{~m}$ on 10 May 2001 and on 19 May 2004.

Each cultivar was harvested by hand one time at prime maturity by pulling up and depodding all plants in $3 \mathrm{~m}$ of each plot (dates of harvest are shown in Tables 1 and 2). Pods were weighed and a random sample (200 g or greater) was taken. Sampled pods were sorted into sieve size classes using a commercial gauge and weighed to determine percentages in each class. Sieve sizes are based on pod diameter with sieve Size 1 ranging from 4.8 to $5.7 \mathrm{~mm}$; sieve Size 2 ranging from 5.8 to $7.3 \mathrm{~mm}$; sieve Size 3 ranging from 7.4 to 8.3 $\mathrm{mm}$; sieve Size 4 ranging from 8.4 to $9.5 \mathrm{~mm}$; and sieve Size 5 ranging from 9.6 to $10.7 \mathrm{~mm}$ (Rutledge, 1996). Twenty-five total pods per plot (sieve Sizes 3 and 4) also were measured for pod length. Samples were taken to the laboratory on each date of harvest, and laboratory analyses typically occurred the next day after overnight storage at $5{ }^{\circ} \mathrm{C}$.

Cooking. Sample pods of 10 cultivars (2001) or 12 cultivars (2004) from the field production trials were prepared to simulate fresh cooked beans by immersing raw beans 


\begin{tabular}{|c|c|c|c|c|c|c|c|c|}
\hline \multirow[b]{2}{*}{ Cultivar } & \multirow{2}{*}{$\begin{array}{c}\text { Harvest } \\
\text { date }\end{array}$} & \multirow{2}{*}{$\begin{array}{l}\text { Avg. length per } \\
\operatorname{pod}^{\mathrm{z}}(\mathrm{cm})\end{array}$} & \multirow{2}{*}{$\begin{array}{c}\text { Yield } \\
\left({\left.\mathrm{Mg} \cdot \mathrm{ha}^{-1}\right)}^{-1}\right.\end{array}$} & \multicolumn{5}{|c|}{ Sieve size (\% by wt. in each class $)^{\mathrm{y}}$} \\
\hline & & & & 1 & 2 & 3 & 4 & 5 \\
\hline Benchmark & 18 June & 14.6 & 10.6 & 2 & 9 & 14 & 63 & 12 \\
\hline Blue Lake 274 & 20 June & 13.6 & 5.6 & 4 & 11 & 24 & 34 & 27 \\
\hline Brio & 22 June & 11.4 & 12.1 & 1 & 3 & 36 & 57 & 3 \\
\hline Castano & 18 June & 12.5 & 6.7 & 2 & 5 & 24 & 50 & 19 \\
\hline Charon & 18 June & 12.3 & 5.7 & 6 & 18 & 41 & 34 & 1 \\
\hline Grenoble & 20 June & 12.1 & 9.1 & 1 & 7 & 50 & 41 & 1 \\
\hline Hialeah & 15 June & 13.4 & 6.4 & 10 & 19 & 44 & 24 & 3 \\
\hline Jade & 20 June & 14.6 & 9.3 & 1 & 2 & 26 & 61 & 10 \\
\hline Mercury & 15 June & 12.4 & 8.1 & 9 & 13 & 25 & 45 & 8 \\
\hline Mirada & 22 June & 10.5 & 10.2 & 2 & 3 & 17 & 58 & 20 \\
\hline Savannah & 25 June & 11.6 & 7.9 & 1 & 4 & 77 & 17 & 1 \\
\hline Seville & 18 June & 13.5 & 7.4 & 6 & 14 & 55 & 25 & 0 \\
\hline Venture & 12 June & 12.9 & 7.7 & 9 & 17 & 35 & 29 & 10 \\
\hline Mean & & 12.7 & 8.2 & 4 & 10 & 36 & 41 & 9 \\
\hline$\underline{L S D}_{0.05}$ & & 1.2 & 2.5 & - & - & - & - & - \\
\hline
\end{tabular}

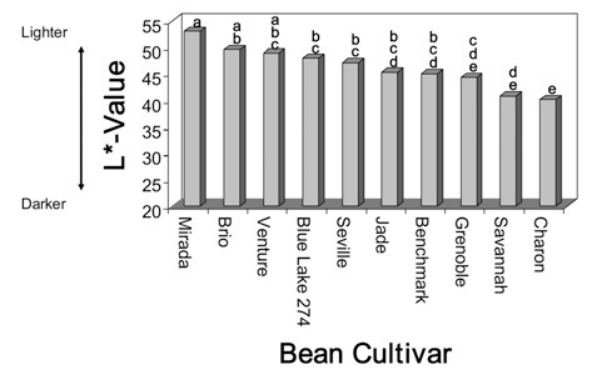

${ }^{2}$ Derived from five random samples of five pods each (mixed sieve Sizes 3 and 4) per cultivar.

${ }^{y}$ Sieve sizes are based on pod diameter, with sieve Size 1 ranging from 4.8 to $5.7 \mathrm{~mm}$; sieve Size 2 ranging from 5.8 to $7.3 \mathrm{~mm}$; sieve Size 3 ranging from 7.4 to $8.3 \mathrm{~mm}$; sieve Size 4 ranging from 8.4 to $9.5 \mathrm{~mm}$; and sieve Size 5 ranging from 9.6 to $10.7 \mathrm{~mm}$ (Rutledge, 1996).

$\mathrm{LSD}=$ least significant difference.

Table 2. Harvest information for 12 snap bean cultivars, Bixby, OK, 2004.

\begin{tabular}{|c|c|c|c|c|c|c|c|c|}
\hline \multirow[b]{2}{*}{ Cultivar } & \multirow{2}{*}{$\begin{array}{c}\text { Harvest } \\
\text { date }\end{array}$} & \multirow{2}{*}{$\begin{array}{l}\text { Avg. length per } \\
\operatorname{pod}^{z}(\mathrm{~cm})\end{array}$} & \multirow{2}{*}{$\begin{array}{c}\text { Yield } \\
\left(\mathrm{Mg} \cdot \mathrm{ha}^{-1}\right)\end{array}$} & \multicolumn{5}{|c|}{ Sieve size ( $\%$ by wt. in each class $)^{y}$} \\
\hline & & & & 1 & 2 & 3 & 4 & 5 \\
\hline Benchmark & 26 June & 12.4 & 6.0 & 4 & 10 & 34 & 40 & 12 \\
\hline Blue Lake 274 & 4 July & 12.0 & 9.0 & 1 & 3 & 14 & 31 & 51 \\
\hline Brio & 30 June & 12.7 & 9.2 & 4 & 12 & 49 & 32 & 3 \\
\hline Capricorn & 4 July & 12.8 & 8.5 & 1 & 4 & 19 & 47 & 29 \\
\hline Charon & 30 June & 12.9 & 9.2 & 3 & 5 & 25 & 46 & 21 \\
\hline Dusky & 28 June & 12.4 & 7.6 & 3 & 7 & 48 & 38 & 4 \\
\hline Grenoble & 28 June & 11.2 & 6.4 & 5 & 13 & 46 & 29 & 7 \\
\hline Jade & 30 June & 14.9 & 7.6 & 2 & 5 & 24 & 47 & 22 \\
\hline Mirada & 30 June & 12.3 & 4.6 & 1 & 5 & 22 & 68 & 4 \\
\hline Savannah & 4 July & 11.2 & 5.6 & 3 & 8 & 55 & 26 & 8 \\
\hline Seville & 30 June & 14.1 & 8.4 & 4 & 7 & 43 & 46 & 0 \\
\hline Venture & 17 June & 12.7 & 5.2 & 4 & 7 & 18 & 48 & 23 \\
\hline Mean & & 12.6 & 7.2 & 3 & 7 & 33 & 42 & 15 \\
\hline $\mathrm{LSD}_{0.05}$ & & 0.6 & NS & - & - & - & - & - \\
\hline
\end{tabular}

${ }^{\mathrm{z}}$ Derived from five random samples of five pods each (mixed sieve Sizes 3 and 4) per cultivar.

${ }^{\mathrm{y}}$ Sieve sizes are based on pod diameter, with sieve Size 1 ranging from 4.8 to $5.7 \mathrm{~mm}$; sieve Size 2 ranging from 5.8 to $7.3 \mathrm{~mm}$; sieve Size 3 ranging from 7.4 to $8.3 \mathrm{~mm}$; sieve Size 4 ranging from 8.4 to $9.5 \mathrm{~mm}$; and sieve Size 5 ranging from 9.6 to $10.7 \mathrm{~mm}$ (Rutledge, 1996).

NS $=$ nonsignificant by F test at $P \leq 0.05$.

LSD $=$ least significant difference.

in boiling water for $10 \mathrm{~min}$ and then immediately cooling in $15{ }^{\circ} \mathrm{C}$ water for $2 \mathrm{~min}$. This process was duplicated for each of the three replicate samples from each cultivar. Cooked beans were drained, placed in a polyethylene bag, and then evaluated for color. Cooked beans were stored at $8{ }^{\circ} \mathrm{C}$ for no longer than $24 \mathrm{~h}$ if immediate color analysis was not possible.

Color evaluation. Surface color evaluations on raw and cooked beans were conducted using a Minolta CM-3500d reflectance spectrophotometer (Minolta Corp., Ramsey, NJ). Bean samples were randomly arrayed in a clear plastic petri dish. Mean sample size was $68.4 \mathrm{~g}$ with a SD of $6.4 \mathrm{~g}$. All color measurements were taken using a $30.0-\mathrm{mm}$ aperture. Each sample was evaluated three times and rotated $120^{\circ}$ between readings to compensate for surface irregularities. Evaluations were averaged to give a final reading for a given bean sample. This process was repeated on duplicate samples. Duplicates then were averaged to give a final reading for each of the three replications. Readings were taken as CIE L* a* b* values using the D65 Standard Illuminant (Commission Internationale de l'Éclairage, 1978). Hue angle for samples was calculated as $\operatorname{Tan}^{-1}$ (b/a) (Little, 1975).

Sensory evaluation. Twenty relatively straight, unblemished pods per cultivar were harvested on 20 June 2001 and on 30 June 2004 from plants of 'Blue Lake 274', 'Brio', 'Charon', 'Jade', and 'Seville'. Pods were tested to confirm that all fit sieve Size 4. The five most uniform pods per cultivar were presented as raw samples that same day to an untrained panel consisting of seven males and 18 females (2001) or nine males and 18 females (2004). Panelists viewed samples under recessed fluorescent lighting in the same room in both 2001 and 2004. The sensory evaluation was designed as an affective test; panelists were asked to rate sensory attributes on a 5-point semantic differential scale. The attributes evaluated were intensity of color and likeliness to buy. A rating of 1 represented lightest green or least likely to buy, whereas a

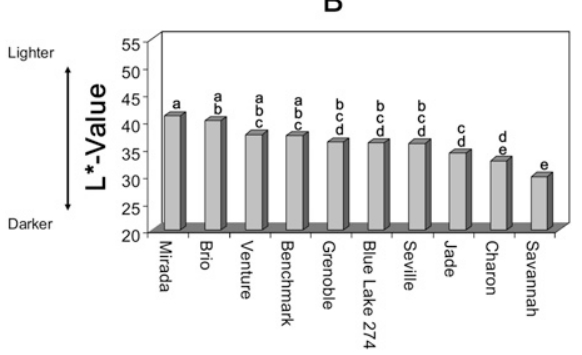

Bean Cultivar

Fig. 1. Mean L* values of raw (A) and cooked (B) green beans in 2001. The value for each cultivar is the mean of three samples. Bars marked with the same letter do not differ at $P \leq$ 0.05 by Duncan's multiple range test.

A

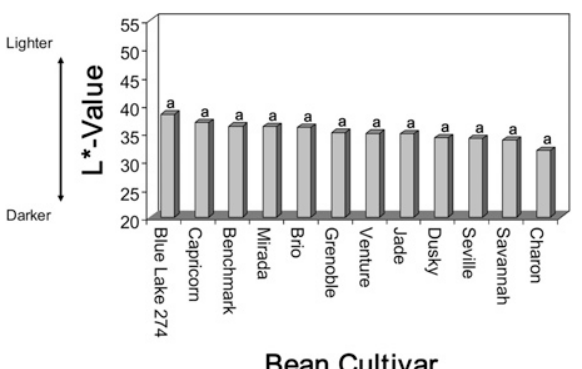

Bean Cultivar

B

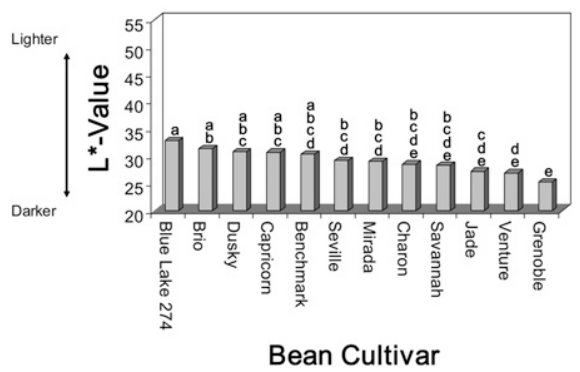

Fig. 2. Mean $\mathrm{L}^{*}$ values of raw (A) and cooked (B) green beans in 2004. The value for each cultivar is the mean of three samples. For the raw beans, the overall F-test for cultivar effects showed no differences at $P \leq 0.05$. For the cooked beans, bars marked with the same letter do not differ at $P \leq 0.05$ by Duncan's multiple range test.

rating of 5 represented darkest green or most likely to buy. Correlation coefficients for the two attributes were calculated.

Statistical analysis. Analyses of variance were conducted within years using the GLM 
A
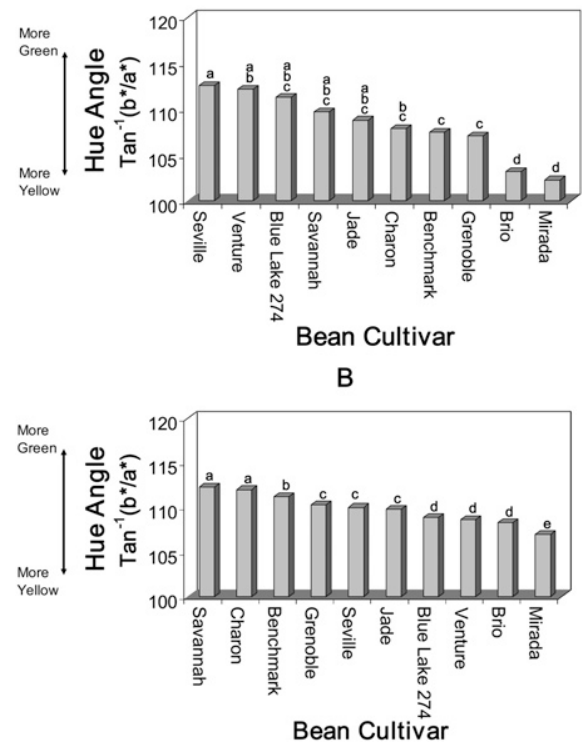

Fig. 3. Mean hue angles of raw (A) and cooked (B) green beans in 2001. The value for each cultivar is the mean of three samples. Bars marked with the same letter do not differ at $P \leq$ 0.05 by Duncan's multiple range test.

A

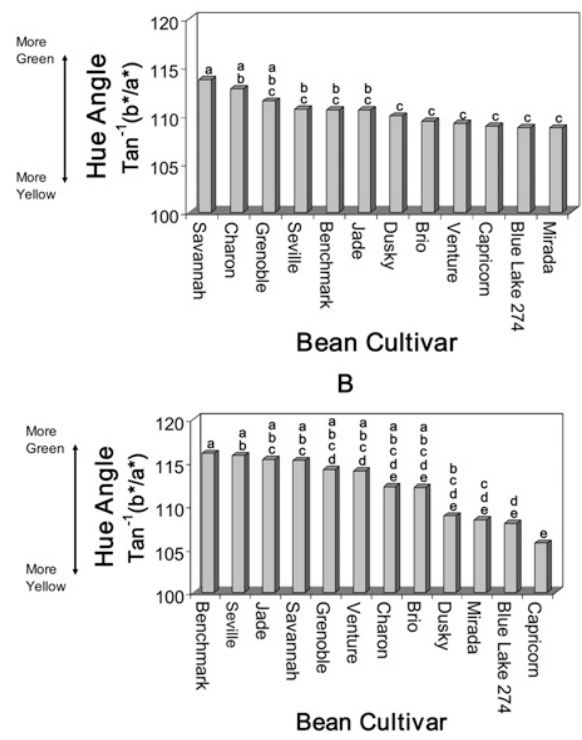

Fig. 4. Mean hue angles of raw (A) and cooked (B) green beans in 2004. The value for each cultivar is the mean of three samples. Bars marked with the same letter do not differ at $P \leq$ 0.05 by Duncan's multiple range test.

procedure of the SAS for Windows Version 8.0 analytical software package (SAS Inc., Cary, NC). Means from the field trials were separated using a protected least significant difference with $\alpha=0.05$. To obtain a sufficiently large sample size, snap bean pod samples were randomized with respect to field block before cooking and color analysis. Thus, color analysis data were analyzed based on a completely randomized design, and means were separated using Duncan's multiple range test with $\alpha=0.05$.
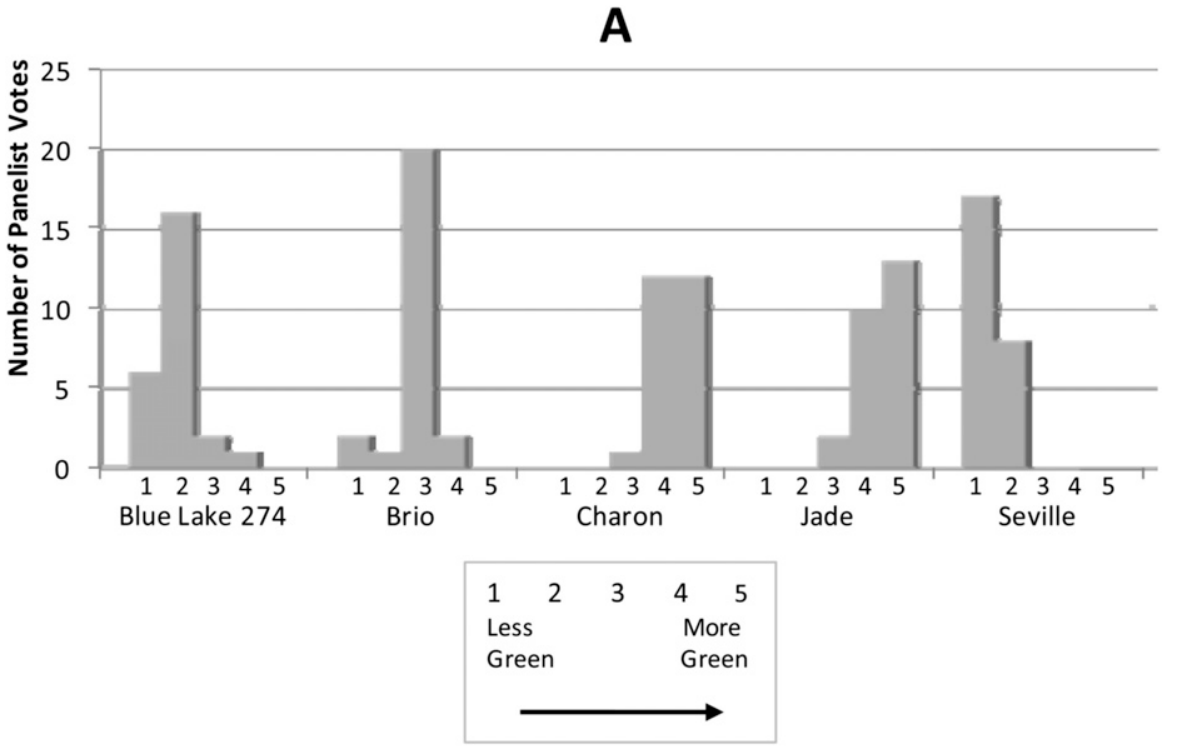

Geen Bean Cultivar

B

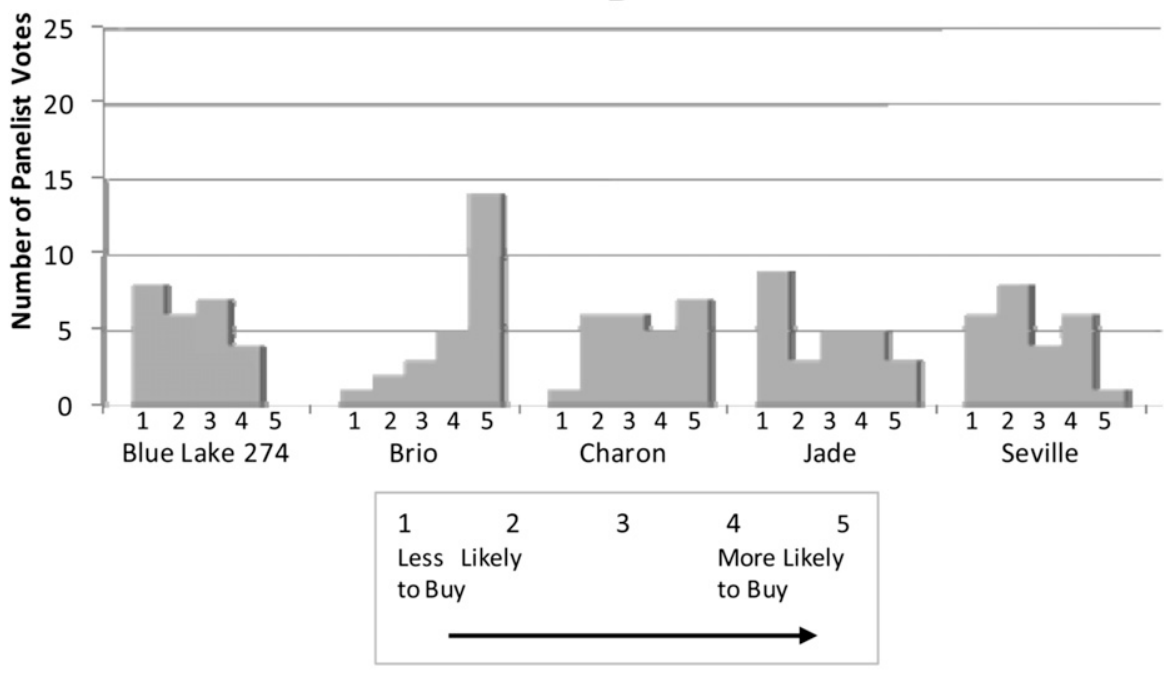

Geen Bean Cultivar

Fig. 5. Green bean sensory panel ratings for intensity of green color (A) and likeliness to buy (B) in 2001 . Samples of raw, intact pods were presented to an untrained panel of seven males and 18 females. Bars are the number of votes in each of five potential ratings categories.

\section{Results and Discussion}

Field production trials. Cultivars varied in pod length in both years and in yield in 2001 (Tables 1 and 2). Relative rankings for pod length tended to be inconsistent between years, except for 'Jade' and 'Seville' with consistently long pods and 'Grenoble' and 'Savannah' with consistently short pods. 'Blue Lake 274' pods did not set uniformly and had a tendency to develop larger sieve sizes while still short, making harvest timing more difficult. The problem was exacerbated in 2004 when harvest of both 'Blue Lake 274' and 'Capricorn' was delayed $48 \mathrm{~h}$ by heavy rain.

Color evaluation. The results for $\mathrm{L}^{*}$ values followed the expected pattern; the cooked beans consistently had a lower $\mathrm{L}^{*}$ value and were therefore darker than the raw beans (Figs. 1 and 2). This is typical for the cooking process used, which removed occluded air from the plant tissues (Tijskens et al., 2001). Raw pods differed in $\mathrm{L}^{*}$ values in 2001 but not in 2004. In both years, significant differences in $\mathrm{L}^{*}$ values were observed after cooking. The beans showed the same general pattern for $\mathrm{L}^{*}$ values across cultivars after cooking as they did before cooking in both years. However, the correlation between raw $\mathrm{L}^{*}$ value and cooked $\mathrm{L}^{*}$ value was significant only in 2001 (correlations not presented). One reason was that in 2004, 'Grenoble' and 'Venture' darkened more after cooking than several other cultivars.

Differences also were seen in hue angle values among the cultivars before and after cooking (Figs. 3 and 4). Cultivars varied more in hue angle than in $\mathrm{L}^{*}$ value, particularly in the cooked samples. In 2001, six of the 10 cultivars examined exhibited an 

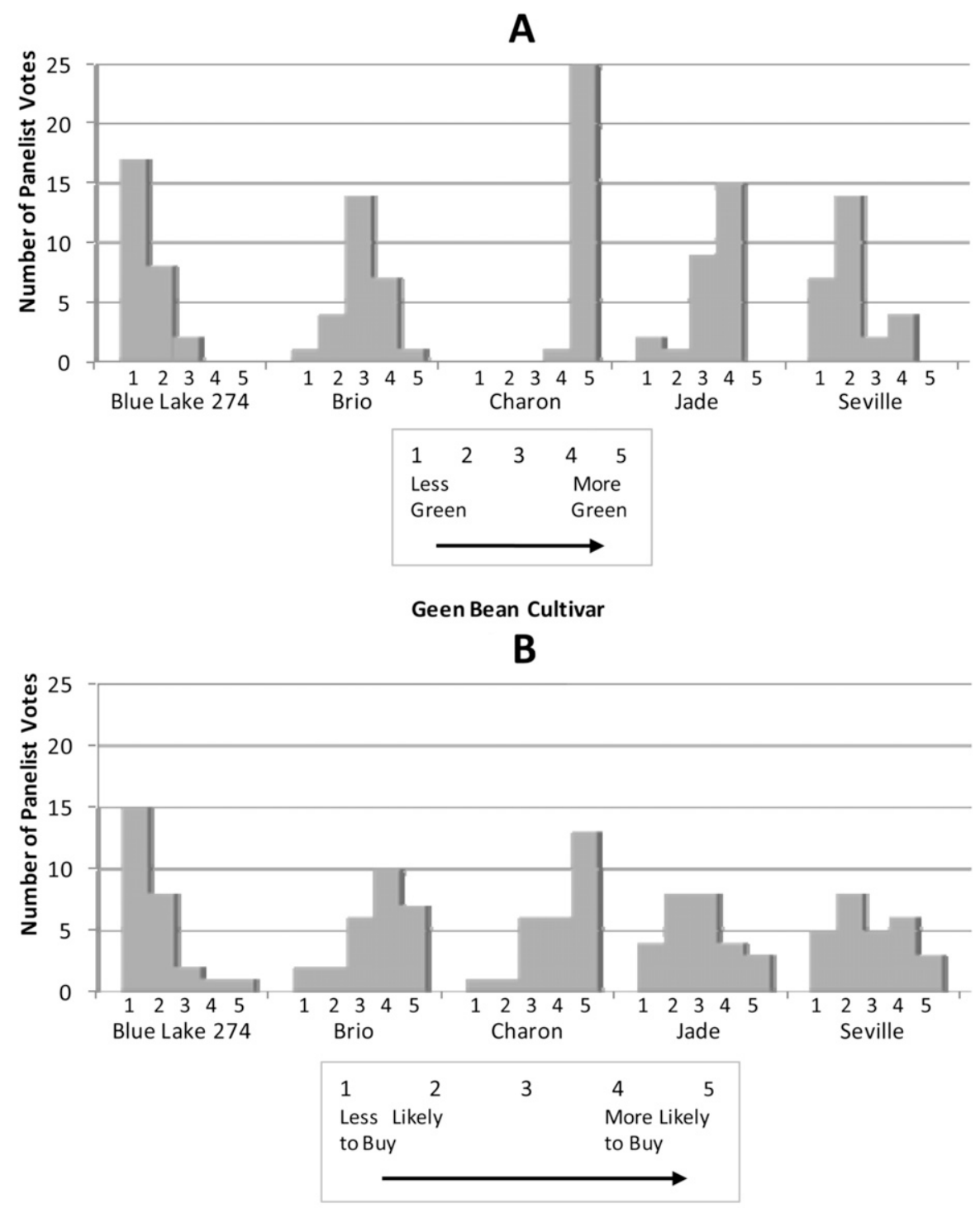

Geen Bean Cultivar

Fig. 6. Green bean sensory panel ratings for intensity of green color (A) and likeliness to buy (B) in 2004. Samples of raw, intact pods were presented to an untrained panel of nine males and 18 females. Bars are the number of votes in each of five potential ratings categories.

Table 3. Objective analyses and sensory evaluations of raw snap bean samples. ${ }^{2}$

\begin{tabular}{|c|c|c|c|c|c|}
\hline \multirow[b]{2}{*}{ Factor } & \multicolumn{5}{|c|}{ Cultivar } \\
\hline & Blue Lake 274 & Brio & Charon & Jade & Seville \\
\hline \multicolumn{6}{|l|}{2001} \\
\hline $\mathrm{L}^{*}$ value & $48.0 \mathrm{bc}$ & $49.6 \mathrm{ab}$ & $40.2 \mathrm{e}$ & $45.2 \mathrm{bcd}$ & $47.1 \mathrm{bc}$ \\
\hline Hue angle & $108.9 \mathrm{~d}$ & $108.3 \mathrm{~d}$ & $112.0 \mathrm{a}$ & $109.8 \mathrm{c}$ & $110.0 \mathrm{c}$ \\
\hline Greenness $^{y}$ & 48 & 72 & 111 & 111 & 33 \\
\hline Likelihood $^{y}$ & 57 & 104 & 86 & 65 & 63 \\
\hline \multicolumn{6}{|c|}{ Correlation $(r)$ of greenness votes to likelihood of purchase votes: $-0.31^{* *}$} \\
\hline \multicolumn{6}{|c|}{$\mathrm{c}$} \\
\hline L* value & $38.3 \mathrm{a}$ & $35.9 \mathrm{a}$ & $31.8 \mathrm{a}$ & $34.8 \mathrm{a}$ & $33.9 \mathrm{a}$ \\
\hline Hue angle & $108.7 \mathrm{c}$ & $109.4 \mathrm{c}$ & $112.7 \mathrm{ab}$ & $110.5 b c$ & $110.6 \mathrm{bc}$ \\
\hline Greenness $^{y}$ & 39 & 84 & 134 & 92 & 57 \\
\hline Likelihood $^{y}$ & 46 & 99 & 110 & 75 & 75 \\
\hline \multicolumn{6}{|c|}{ Correlation $(r)$ of greenness votes to likelihood of purchase votes: $0.67^{* *}$} \\
\hline
\end{tabular}

${ }^{2}$ Within years and within rows, means followed by the same letter do not differ at $P \leq 0.05$ by Duncan's multiple range test. Letters may not be sequential since analyses included more than the five cultivars shown in this table.

${ }^{\mathrm{y}}$ Totals by cultivar using a weighted scale. The number of ratings in each category was multiplied by the weight factor for each category, in which $1=$ lightest green or least likely to buy and $5=$ darkest green or most likely to buy.

${ }^{* * *}$ Significant at $P \leq 0.01$. increase in hue angle after cooking, indicating a shift to a more green hue. Increases were most pronounced for 'Brio' and 'Mirada'. The three cultivars with the highest hue angle values before cooking (Blue Lake 274, Seville, and Venture) exhibited a decrease in hue angle after cooking, indicating a shift to a more yellow hue. The hue angle of 'Jade' was essentially unchanged after cooking. In 2004, seven of the 12 cultivars examined exhibited an increase in hue angle after cooking. Two of these, 'Seville' and 'Venture', had exhibited decreases in hue angle after cooking in 2001. 'Blue Lake 274', 'Capricorn', and 'Dusky' exhibited a decrease in hue angle after cooking, whereas the hue angles of 'Charon' and 'Mirada' were essentially unchanged after cooking. Thus, the changes in hue angles as a result of cooking were not consistent between years or among cultivars. The "dark green" cultivars (Charon, Dusky, Jade, and Savannah) were not necessarily in the top statistical grouping for hue angle value (darkest green) in either the raw form or after cooking.

The observed changes in hue angle after cooking may have resulted from a number of factors. Pigment concentrations may have changed as a result of cooking. For example, chlorophyll may have been lost in the cook water (Lee, 1958) or may have degraded to other forms such as pheophytin (MacKinney and Weast, 1940). The apparent visibility of the pigments present in the beans was certainly altered by the increased tissue translucence caused by cooking. Our studies were not designed to investigate factors causing the changes in hue angle as a result of cooking. However, we have demonstrated that the hue angles of the green beans tested did change as a result of cooking, and the changes seen were not uniform among cultivars.

Sensory evaluation. Results are presented in Figures 5 and 6 and in summary form in Table 3. One would expect that the eye would perceive the combination of a low $\mathrm{L}^{*}$ value (dark) and a high hue angle (more green than yellow) as being the darkest green. This was typified by 'Charon'. However, in 2001, the panel rated 'Charon' and 'Jade' as equivalent in greenness, although 'Charon' was lower in $\mathrm{L}^{*}$ value and higher in hue angle than 'Jade'. There was no consistency between years, because in 2004, 'Charon' and 'Jade' did not differ in $\mathrm{L}^{*}$ value or hue angle, but 'Charon' was rated as more green than 'Jade' by the panel (Table 3). In both years, 'Charon' was rated as more likely to be purchased than 'Jade', but 'Charon' was second overall in likelihood of purchase to the lighter green (by both objective and subjective measures) 'Brio' in 2001

Another comparison of interest is between 'Jade' and 'Seville'. In both years, these cultivars did not differ in $\mathrm{L}^{*}$ value or hue angle, but they clearly looked different in greenness to the panelists. Despite the apparent perception of differences in greenness, ratings of likelihood of purchase for the two cultivars were very similar in both years (Table 3 ). 
'Blue Lake 274' was rated as the cultivar least likely to be purchased in both years, but the reasons were not readily apparent. Objectively, it tended to have a low hue angle (more yellow than green), but statistically it was no different in hue angle or $\mathrm{L}^{*}$ value in both years from the more highly rated 'Brio' (Table 3 ).

Correlations $(r)$ of greenness votes to likelihood of purchase votes were significant in both years, but in opposite directions, and neither reached a value of 0.70 (Table 3 ). The overall correlation of greenness votes to likelihood of purchase votes across the 2 years was $r=0.42$, significant at $P \leq 0.01$ but not strong. Mayland and Dean (1971) noted that objective measures of greenness do not completely account for characteristics that stimulate visual color grading as illustrated by correlation coefficients of $\leq 0.70$.

We can only speculate about factors other than greenness that may have influenced likelihood of purchase. One possibility is the degree of seed development or "lumpiness." Although all pods viewed by the panelists were carefully screened for uniformity, straightness, and consistent sieve size, a few panelists in 2001 remarked that some pods of 'Jade' exhibited visible seed development. Silbernagel and Drake (1978) stated that snap bean cultivars differ in seed content in their pods. They also observed that the perceived degree of seed development can be affected by variations in pod size relative to seed size and shape.

\section{Conclusions}

The results of our objective color evaluations suggest that color testing of raw snap bean pods may not be sufficient to determine the color after cooking. Although $\mathrm{L}^{*}$ values may be expected to decrease after cooking, the magnitude of the changes may not be predictable. Changes in hue angle values after cooking appear to be even more variable among cultivars. Therefore, if the color of the cooked beans is expected to be a deciding factor in cultivar selection, we would recommend conducting color tests on cooked bean pods as well as the raw product.

Sensory panel results indicated that panelists were able to make subjective distinctions among the cultivars based on color. However, these differences did not necessarily correlate with either objective color measures or likelihood of purchase. Others (Frank et al., 2001; McBride and Anderson, 1990) also have concluded that interactions among various sensory perceptions of consumers, including color and appearance, may be complex and that objective measurements of a single sensory variable may not be sufficient to predict a food's subjective appeal. Our findings specifically support those of Brooker and Eastwood (1992); snap bean pod color is not an overriding selection criterion, but only one of many criteria considered by consumers.

\section{Literature Cited}

Brooker, J.R. and D.B. Eastwood. 1992. Consumer and food industry acceptance of a new green bean. J. Food Distrib. Res. 23:19-27.

Commission Internationale de l'Éclairage. 1978. CIE recommendations on uniform color spacesColor difference equations, psychometric color terms. CIE Publication 15, Supplement No. 2:9-12.

Frank, C.A., R.G. Nelson, E.H. Simonne, B.K. Behe, and A.H. Simonne. 2001. Consumer preferences for color, price, and vitamin $\mathrm{C}$ content of bell peppers. HortScience 36:795800

Gamble, J., S.R. Jaeger, and F.R. Harker. 2006. Preferences in pear appearance and response to novelty among Australian and New Zealand consumers. Postharvest Biol. Technol. 41:3847.

Hoffman, J.C. and M.S. Kanapaux. 1955. Relation of visual color rating to chlorophyll contents of snap bean pods. Proc. Amer. Soc. Hort. Sci. 66:339-344.

Kramer, A. 1951. Objective testing of vegetable quality. Food Technol. 5:265-269.

Lee, F.A. 1958. The blanching process. Adv. Food Res. 8:63-109.

Little, A. 1975. Off on a tangent. J. Food Sci. 40:410-411.

Lopez-Hernandez, J., L. Vazquez-Oderiz, E. Vazquez-Blanco, A. Romero-Rodriguez, and J. Simal-Lozano. 1993. HPLC determination of major pigments in the bean (Phaseolus vulgaris). J. Agr. Food Chem. 41:1613-1615.

MacKinney, G. and C.A. Weast. 1940. Color changes in green vegetables-Frozen-pack peas and string beans. Ind. Eng. Chem. 32: 392-395.

Mayland, H.F. and L.L. Dean. 1971. Chlorophyll content of persistent-green and normal snap bean pods (Phaseolus vulgaris L.). J. Amer. Soc. Hort. Sci. 96:362-365.

McBride, R.L. and N.H. Anderson. 1990. Integration psychophysics, p. 93-115. In: McBride, R.L., and H.J.H. MacFie (eds.). Psychological basis of sensory evaluation. Elsevier, New York, NY.

Muftugil, N. 1986. Effect of different types of blanching on the color and the ascorbic acid and chlorophyll contents of green beans. J. Food Proc. Preserv. 10:69-76.

Rutledge, A.D. 1996. Commercial snap bean production. Univ. Tenn. Agr. Ext. Serv. PB 897.

Silbernagel, M.J. and S.R. Drake. 1978. Seed index, an estimate of snap bean quality. J. Amer. Soc. Hort. Sci. 103:257-260.

Tijskens, L.M.M., E.P.H.M. Schijvens, and E.S.A. Biekman. 2001. Modeling the change in colour of broccoli and green beans during blanching. Innovative Food Sci. \& Emerging Technol. 2:303-313. 